\title{
Self and the Quest for Ideal Existential Space: a Study of Jack Kerouac's On the Road
}

\author{
Saumya Bera ${ }^{1} \&$ Soumyajyoti Banerjee ${ }^{2}$ \\ ${ }^{1}$ Assistant professor, Haldia Institute of Technology. Haldia, Dist- Purba Medinipur, West \\ Bengal, India, 721657. ORCID: 000o-0002-1198-9366. \\ Email: berasaumya@gmail.com \\ ${ }^{2}$ Assistant professor, Haldia Institute of Technology.
}

Received November 27, 2017; Revised March 28, 2018; Accepted March 31, 2018; Published May o6, 2018.

\begin{abstract}
:
The present study seeks to explore questions of formation, discernment and inspection of the individual identity through the exploration of existential space. This idea has been explicated through the narrative of Sal in the selected text who attempts to disembark at an understanding about the entirety of human existence. In the present study, Sal begets an identity in his mental space, which is devoid of any rootedness to his present contextual existence. This very realization drives him to go on the road in search of an ideal existential space that might resonate his own 'self. However, in doing so, he actually looks for an existential space to form his own identity which consequently gives birth to the conflict, the existential angst. His attempt to 'be' by idealizing the 'other' and assimilating the 'otherness' halts the process of formation of identity. Therefore, Sal's imagination of 'self and 'other' fades away in an unending loop of deference. The study intends to employ the theoretical tool of Existential Space to understand the imaginary constructs that inform the creation and evaluation of the identity of the individual.
\end{abstract}

Keywords: self, identity, quest, idealization, existentialism, space

\section{Introduction:}

An absolutist approach to meaning is premised on the idea that there is a fundamental, irreversible foundation on which human ontology is based. From this it can be derived that each individual's existence would emerge from this essence - that his or her "nature" would be determinative of actions taken, choices made and so on.

"The entire classical philosophy from Plato to Hegel is one of a rationalist-objectivist quest for eternal truths. This philosophical tradition posits that human reality is overshadowed by the universal over the particular, the necessary over the contingent and essence over existence. Various systematic approaches to high metaphysical abstraction result in theories about static universals, and the dynamic particularities of individual human existence are unscrupulously subsumed under general truths; such as, 'the real is the rational, and the rational is the real"'. (Sarin, 1996, pp. 181)

Existentialism rejects this essentialism and suggests an alternative form in which "existence precedes essence." Therefore, what is regarded as a person's "nature" (personality, character, identity) is a construction based on life experience. That is, who we are is fashioned by the choices

(c) AesthetixMS 2018. This Open Access article is published under a Creative Commons Attribution Non-Commercial 4.0 International License (http://creativecommons.org/licenses/by-nc/4.o/), which permits non-commercial re-use, distribution, and reproduction in any medium, provided the original work is properly cited. For citation use the DOI. For commercial re-use, please contact editor@rupkatha.com. 
we make, the actions we undertake, and the meanings we form from them. The creation of the "self "takes place at the threshold of popular dialectics and personal subjectivity, between instinct and inhibition" (Banerjee, Singh, Basu, 2016, pp.278). Our sense of self, then, is not an underlying "essence," but rather a construction-a work in progress. Sartre's version of existentialism encapsulates this point in his contention that we are what we make ourselves-that is, each person's identity is an evolving process, rooted in the actions and meanings that make up existence, rather than a fixed entity ingrained in a supposed "essence." Identity is therefore conditional and subject to flux, rather than essential. The thrust is for the search for truth: an existential inwardness, a subjective space where existential decisions are made with utmost freedom. This inner space, constituted by inner freedom, is one of existential authenticity born out of a persistent engagement in subjective contemplation.

Sal Paradise, the protagonist of Jack Kerouac's On the Road appears as a rebel and dissenter who takes to the road in the American hinterland with the anticipation of meeting his personal destiny on the way. His failure to reconcile with the pre-packaged essence that creates his social identity makes his existence vulnerable. He begins to feel that security, safety and establishment are a facade that is subject to destruction. As a result he embarks on a crosscountry travel in search for his emotive identity through idealization of the Other. For Sal, to get to know his self is - in large part - a question of coming to understanding the configuration of his Identity.

In academic and critical quarters Sal Paradise is a much discussed character who has been subject to numerous interpretations. He is the quintessential dissident of what has been called the Beat-generation, a non-conformist caught between "[...] the polar tensions of spontaneity and artifice, improvisation and contrivance" (Tytell, 1979, pp. 327) and who "[...] passionately embraced the extreme of uncontained release and denounced superimposed and confining forms" (Tytell, 1979, pp. 327). As Ligairi puts it, "Foremost in Sal's desire to move across the physical space of the United States is a yearning to undergo firsthand a wide range of 'authentic' experiences" (Ligairi, 2009, pp. 144). Sal cites alibi to his flights when he claims that all his "New York friends were in the negative, nightmarish position of putting down society and giving their tired bookish or political or psychoanalytical reasons...." (Kerouac, 200o, pp. 8). To take to the road is initiation ritual and educational foray, as well as a rebellion against the given circumstances (Widmer, 1965, pp. 96). Critics, however, are divergent as to the reasons, elements and consequences of Sal's travels. Arnold Krupat notes that "the compositional logic of On the Road is apocalyptically religious rather than formally artistic" (Krupat, 1979, pp. 397). Vopat describes Sal's propensity as one of embellishment and which is somewhat suspicious on Sal's part. Others conversely state that "Sal's discourse is throughout emotional, impassioned, honest, and open, and it is meant to be taken at face value" (Malmgren, 1990, pp. 207). Commenting on Sal's intentions Hilary Holladay observes that "[...] Sal yearns to walk in the shoes of an Other" (Holladay, 2009, pp. 110). Critic Lars Larson suggests that Sal's experience of other cultures is miniscule on the temporal scale. He writes of Sal:

"He positions minorities as living a bliss of emotional extremes, and while he feels he can sample this freedom by inhabiting racialized spaces [...] the experience is frustratingly temporary" (Larson, 2009, pp. 44).

In Mexico Sal hopes "to confront the primal source of pure being, to discover life as it wasshapeless, formless, dark-before being molded into self and society; in short, to find once and for all the womb he has been seeking for all his life" (Vopat, 1979, pp. 446). As regards Sal's objective and its outcome F. Feied asserts that "this fugue, this flight, is portrayed as an attempt to escape 
from an intolerable personal or social situation, and on the symbolic level as a search for values or the inner light and understanding, a search for the road, the way to spiritual truth, in short, a search for God" (Feied, 1964, pp. 61). Banerjee et al. argues the search for "the true"self becomes essential as an act counter to the appropriating stance of historiographical narrative of interpretations" (Banerjee, Singh, Basu, 2016, pp. 276). While Larson posits that in a way, his quest is resolved; he writes,

"For him, this relativity confirms the desires he has had all along: that American norms are not at the center of humanity. It seems to justify his past differences with his nation's set of proprieties and responsibilities and permits him to explore them in the future" (Larson, 2009, pp. 47)

Tim Hunt writes that Sal, "[...] is willing to enjoy what comes his way without justifying himself through the hyperbole" (Hunt, 1981, pp. 61). Sal, says H. Webb, "is caught between the present of the novel and the past, which he has never fully left, and who cannot go back” (Webb, 1964, pp. 125). Sal, thus, emerges as a unique character: an archetypal anarchist, a dystopian cynic, an avant-garde progressive and an impassioned seeker. Overall Sal Paradise is the epitome of the modern man in search of his existential space which can be called 'the Self.' The present study seeks to explore questions of creation, perception and examination of the individual Self as explicated through the narrative of Sal in the selected text and to arrive at an understanding of the ontology of the human experience. The study intends to use the theoretical tool of Existentialism, specifically Existential space to interrogate the ideological constructs that inform the formulation and evaluation of the Self of an individual.

\section{Situating the Theory: Existential Space and the Individual}

The spatial understanding is "a dimension of human existence and not merely a dimension of thought and perception, essential for orientation and action in the environment" (Schulz, 1971, p.9). Existence takes place by orienting to objects which manifest through the psychosomatic and cognitive procedures involved in perception. Existence in the corporeal level cannot be envisioned disjointedly from the experience of space, as it speaks about our perception-of and behaviour-in "space" and is therefore reliant on our awareness of this space, around us and beyond (Charitos, 1996, pp. 3). "Most of man's actions comprise a spatial character, in a sense that objects of orientation are distributed according to spatial relations." (Benedikt, 1991, p.125) The individual's understanding of space consists of the anxiety between one's immediate condition and existential space (Charitos, 1996, pp. 4). When our immediate locality coincides with the centre of our existential space, we experience "being at home". If not we are either "on our way", "somewhere else", or we are "lost"." (Schulz, 1971, p.34)

The spatial experience of an individual is further enhanced by the following concepts:

"Ambient space is the objective, measurable space defined by surfaces and objects that we design and build and which correspond to the lower-level perceptual processes which inform orientation in the environment." (Charitos, 1996, pp. 5)

"Hodological space (from the greek "odos") is identified with the activity of movement through space. Not only towards a visible goal but also towards a nonvisible destination, which requires a mental map." (Mitropoulos, 1975, p.201) Schulz (1971) translated Lewin's (1938, p.54) term of hodological space as "space of possible movement". It is a subjective, behavioural space, which is 
determined by an additional parameter: the immediate state of mind of the subject or the specific situation for movement (Charitos, 1996, pp. 5).

"We are born with hodological space, but not with ambient space. We build ambient space allowing for hodological space." (Mitropoulos, 1975, p.200).

The interface of ambient and hodological space creates the concept of centre. Man's space is subjectively centred. (Schulz, 1971, p.18) "The centre represents to man what is known in contrast to the unknown and uncertain world around. By centre Schulz means places of action, where particular activities are carried out. Actions are only meaningful in relation to particular places, and are coloured by the character of the place. This character must be understood as a product of its interaction with its surroundings, which include other elements of existential space." (Charitos, 1996, pp. 7)

"A place is always limited" (Charitos, 1996, pp. 7) and Schulz (Schulz, 1971, p.20) proposes that for its definition, the place needs a pronounced limit or border. As all places are in a way bound by certain limits, they can be experienced as an "inside" in contrast to the surrounding "outside". For Relph (1976, p.114, as quoted in Bonnes and Secchiaroli, 1995, p.164) "existential insideness" (the degree to which people feel a part of a place) as opposed to "existential outsideness" (which involves feelings of strangeness and separation from the place) is the foundation of the place concept (Charitos, 1996, pp. 5). Only when the relations between "inside" and "outside" are defined, man can "dwell", that is "remain", "stay in a place", but also "be brought and remain in peace", "be safeguarded", according to Heidegger (1971, p.146,149).

The idea of path consists of an initial starting point and a way to be followed towards an end, through a chain of places and actions. These actions and events give the path a character of its own. (Charitos, 1996, pp. 5) "What happens along the way is added to the tension created by the goal to be reached, and the point of departure left behind. In certain cases the path has the function of being an organizing axis for the elements by which it is accompanied, while the goal is relatively less important." (Schulz, 1971, pp.22-23)

Where does the path take us, after all? We use different techniques of travelling: those of the body and of the sight. Maurice Merleau-Ponty connects vision to the movement of body:

"My mobile body makes a difference in the visible world, being part of it; that is why I can steer it through the visible. [---] In principle all my changes of place figure in a corner of my landscape; they are recorded on the map of the visible. [---] The visible world and the world of my motor projects are each total parts of the same Being. This extraordinary overlapping, which we never think about sufficiently, forbids us to conceive of vision as an operation of thought that would set up before the mind a picture or a representation of the world, a world of immanence and of ideality. Immersed in the visible by his body, itself visible, the seer does not appropriate what he sees; he merely approaches it by looking, he opens himself to the world." (Merleau-Ponty, 1962, p.162.)

The continuous dialogue between man and the world; the idea of the world inside me, and of me inside the world is the basis of metaphysical ontology for Merleau-Ponty. The idea of leaving home, departing to the road, is in vision and in meeting with the Being at the crossroads, thus experiencing that one belongs to the world. The result is an extension of the private world, the assembling and absorbing of a number of things in one's personality. This means an improvement of self-realisation and the styling of one's way of existence in the world. 


\section{Analysing the text:}

It has often been asserted that Existentialism had a great influence upon the Beat Generation, and by reading On the Road, we think one would be hard pressed to argue otherwise. In Beat Culture and the New America, Lisa Philips opines that "[the Beats] have sometimes been called American existentialists. They indeed shared a sense of acute alienation, of the absurd ...with their European counterparts" (Philips 29). This sense of alienation and despair is encapsulated by the narrator of On the Road in the followings lines: "the raggedy madness and riot of our actual lives, our actual night, the hell of it, the senseless nightmare road. All of it inside endless and beginningless emptiness" (Kerouac, 2000, pp. 254). Life, as Sal understands it, appears to be "senseless."

There are many who live their lives without feeling at ease with their own ways. In Jack Kerouac's On the Road, Sal Paradise, experiences a similar situation. A person responds in a particular way to a specific situation. This response is a combination of an action by the person on the environment (assimilation), and the action of the environment on the person (accommodation), as a result of which the person and the environment surrounding him is modified to obtain an equilibrium (adaptation).

To resolve his existential conflict he adopts a lifestyle of travel, sampling other cultures and places in hopes that he, too, can live in the simple reality of people radically different from him. He is tempted to invent illusory realms to the desire for refuge from a world which is perceived as alien instead of something which people bear the responsibility of creating. According to Buber, the person who regards the world or his immediate spatial experience as an 'It' lives in 'severance and alienation', and is without a 'home, a dwelling in the universe' (Buber, 1937, 58,115). That person is always away from his 'centre'. Buber shares the Existentialist's view that a tendency to regard our spatial experience in the world as alien, as 'It', is implicit in the very nature of consciousness: a tendency aided and abetted by dualistic metaphysics. This encourages people to 'split' experience, wrongly, into two independent factors: a 'ghostly I' and a 'ready-made world' (Buber, 1937, p.21, 26.). For Sal, being on the road is both an escape from Existentialist angst as well as an escape from middle class values of his immediate societal experience. Sal's escape on the road therefore symbolises his spatial anxiety and his journey through the path indicates his attempt to find a temporal answer to his existential quest. By escaping one set of values, however, he ends up espousing another. He overvalues these spatial existences and disturbs the equilibrium of his and his environmental 'schemata', causing him further dissatisfaction with his own lifestyle. Kerouac makes it clear that Sal Paradise constantly spatially idealizes the lifestyles of others in his quest for the authentic, a life devoid of phoniness. This path of idealization convincingly affects the spatial and temporal behaviour of Sal by leaving a mark on his cognitive mapping of 'other' spatial environments that he endeavours to absorb.

Having lived in the same city for years, Sal wants to experience something new and genuine, escaping the harshness of his New York life to a new hodological space, a preferred path, not necessarily a linear one, but a decision based on physical spatial distance, safe route, minimal work and maximum experience. Sal claims that "All my other current friends were intellectuals" (Kerouac, 200o, pp. 9). He likens their judgmental behaviour to a nightmare, demonstrating the horror he feels for his friends' critical nature. By going on the road, Sal hopes to flee from the pessimistic spatial environment he belongs to, forgetting that the answer to his existential question is in the problem itself; it is not exclusive to the problem.

Sal's decision to go on the road is fundamental in understanding how the spatial nuance of the path affects him. Sartre complained that there is something 'magical' or 'fetishistic' in the idea of a human being as a 'subjectivity-object', and Buber's 'I-It' relation was his metaphor for the 
subject-object dualism. At the root of this hostility, there lies the sense, inherited from Hegel, that the subject-object dichotomy is an alienating one. The first time he goes on the road he is yearning for a new narrative of his life. Fresh out of college, Sal sees in Dean an opportunity to explore what he has always been curious about. At the beginning of the novel he hopefully proclaims, "A western kinsman of the sun, Dean...I could hear a new call and see a new horizon, and believe it at my young age" (Kerouac, 2000, pp. 10). Sal's excitement and purpose can be seen through his hopeful and eager language, mentioning a "new horizon", that he hopes to discover by surprise somewhere away from his centre--- his home. Dean offers a glimpse of the excitement that lies beyond his current location. Critic Rachel Ligairi highlights that Sal is restless in his current position. "Sal's first reaction is to get moving in order to avoid the stasis of the era's social conformity" (Ligairi, 2009, p.144). Sal longs to break out of his small reality to experience some individuality, which he does through exploring other cultures through time and space. Going on the road is a means for Sal to find a new direction for his existence and to explore the spatial world and find the authenticity he is looking for.

Escaping through space also represents some amount of irresponsibility for Sal. The "halfway mark" (Kerouac, 200o, pp. 9) of Sal's novel seems to him a perfect time to leave New York to explore the country, leaving his work incomplete. He decides to take a break and continue his work in California. As critic Carole Vopat states, "Kerouac's characters take to the road not to find but to leave it all behind: emotion, maturity, change, decision, purpose, and, especially, in the best American tradition, responsibility" (Vopat, 2000, p.196). Vopat points out that this abandoning of reality and escaping responsibility is not something new and un-American, calling an abandon of responsibility like Sal's an "American tradition". Kerouac seeks to connect with his American audience through Sal's own abandonment of concern and pursuit of newness. Using road trips, a classic American flee from the tedium of everyday stereotyped existence, Kerouac portrays Sal's irresponsibility in order to later show the effects of this recklessness. Though Sal longs to experience something clearly unconventional, his journey itself is not something unique. In the words of Ann Charters, "Sal chases the dream back and forth on the highways between the East and West coasts, and finds that the dream has little staying power, that it's merely a 'sad paradise when he finally catches up with it in New Orleans, Denver, San Francisco, Chicago, and New York." (Ann Charters, xxi, in Jack Kerouac's On the Road)

Sal fulfils this longing for creating his ambient space for leading a true life by reacting with overstated emotions of excitement or pleasure to anything potentially authentic. Sal even portrays small details as fantastic to modify his spatial environment, for something as simple as describing a rainy day.

"It was drizzling and mysterious at the beginning of our journey. I could see that it was all going to be one big saga of the mist" (Kerouac, 2000, pp. 120).

Calling the rain a "saga," Sal is enthralled by something quite normal, a habit he extends to individuals he meets on the road. Describing Sal's tendency, critic Carole Vopat states that "he responds to experience in a language of exaggeration; everything is the saddest or greatest or wildest in the world" (Vopat, 2000, p.196). In his case the experience of space becomes the tension between the existential space and the occupied space at the given moment. Sal fears an unadorned perspective without such exaggerated emotions, and idealizes almost all the places and people he meets on the road. Sal does not judge his own life by the same exaggerated standards and views himself as disappointing when compared to the disproportionately amazing lives of others in a different spatial context. 
Another factor leading Sal to frustration with himself is the brevity of his forays into the authentic life and his journey itself signifies his temporal gratification. He makes a grave mistake by interpreting the temporal as eternal. Critic Lars Larson maintains that though Sal is able to experience other cultures on a smaller scale, he can only spend a limited amount of time with each one of them. Sal is eventually disappointed by his short-lived ventures. Taking a break from the road by getting a job in Denver, Sal dejectedly claims, "I felt like a speck on the surface of the sad red earth" (Kerouac, 200o, pp. 163). He views his life as insignificant, "a speck" after comparing himself to others. All Sal is looking for is the sense of originality he has felt temporarily with others on the road. He longs to experience lasting authenticity, but travelling through time and space will fail to satisfy his craving.

Sal seeks this novelty through the people he meets and the places he discovers on the road and tries to turn his hodological space into an ambient one, so that it gradually attains the status of an existential place. More than anything, Sal overstates the simplicity of minority life, putting their existence in a position of transcendental realness. Alone in Denver Sal laments,

"I wished I were a Denver Mexican, or even a poor overworked Jap, anything but what I was so drearily, a 'white man' disillusioned...I was only myself, Sal Paradise, sad, strolling in this violet dark, this unbearably sweet night, wishing I could exchange worlds with the happy, true-hearted, ecstatic Negroes of America” (Kerouac, 2000, pp.163-164).

Sal is willing to go to extremes to partake in the thrilling and "ecstatic" existences of minorities. Critic Hilary Holladay captures Sal's desires when she states “To be reborn into the life of an ethnic minority would enable him, he thinks, to escape the sorrows and difficulties of his white man's existence" (Holladay, 2000, pp. 110). Holladay is almost mocking Sal's desires, and by belittling his dissatisfaction with his "white man's existence" it is clear to the reader that Sal's dissatisfaction is a trivial idea. He was trying to relate the inside of a space with the outside through by giving a direction to his journey and thereby creating new openings for himself. However, his 'existential outsideness' never takes the form of 'existential insideness' through the process of his quest. Therefore, through his idealizations of minorities, Sal causes himself discontentment.

Sal's dissatisfaction also stems from his emphasis on race and the spatial behaviour of the people of different race, which can be seen especially through his descriptions of others where he was trying to celebrate some neglected spaces of America; because Sal's spatial behaviour is influenced by his own cognitive map of different spatial environments. For him the marginalised spatial experience becomes ideal as this gives him the opportunity to escape and forget his actual spatial environment. His first encounter with Terry, a girl he lives with for many weeks, is characterized by his classification of her. He describes their first encounter, claiming, "...all of a sudden I saw the cutest little Mexican girl in slacks come cutting across my sight" (Kerouac, 20oo, pp. 73). Rather than seeing Terry as a cute girl he is interested in, he specifically defines her as a "Mexican girl", which shows that he is more inclined to the spatial concept of a Mexican girl than the girl herself. Also by highlighting race before actual personality, Kerouac shows that Sal is more focused on finding something new for himself, in this case through a different racial and spatial existence. Sal believes that, "in her simple soul she couldn't fathom my kind of glad, nervous talk" (Kerouac, 2000, pp. 84). His dualism is never dissolved as he is always impulsively following his instincts as his fascination for Terry quickly transforms from '...this was my girl and my kind of girlsoul' to 'a dumb little Mexican wench', when he is not able to poise the inner space of Terry with that of his own (Kerouac, 2000, pp. 74, 76). The same happens when his description of LA dramatically shifts from '...the ragged promised land, the fantastic end of America' to 'LA is 
the loneliest and most brutal of American cities' (Kerouac, 20oo, pp. 74- 77). Being incapable to equate his 'existential insideness' with his 'existential outsideness', he is unable to realize his own 'inward space'.

Not only does Sal romanticize Mexican-Americans, he does the same for Mexico and the native people of Mexico. "These people were unmistakably Indians and were not at all like the Pedros and Panchos of silly civilized American lore-they had high cheekbones, and slanted eyes, and soft ways; they were not fools, they were not clowns, they were great, grave Indians and they were the source of mankind and the fathers of it" (Kerouac, 2000, pp. 255). Although he rejects the typical American idealization of the Indians, he creates his own, likening the Indians to great protectors of the Earth. He calls them "the source of mankind," viewing them as stoic creatures rather than real people. Critic Tim Hunt captures Sal's romanticism when he writes,

"The magic and holiness Sal and Dean perceive in Mexico comes from the same source. They see Mexico as primitive. Its people live in a manner so old and fundamental that they are before history and timeless. To Sal, it is 'the golden world that Jesus came from'..." (Kerouac, 2000, pp. 64).

Hunt brings attention to Sal's placement of these people in an above-human status. If this surreal authenticity is what Sal seeks for his own life, he is practically destined to be dissatisfied with what he finds, since he does not put himself in the spatial and temporal position of the omnipotent.

In addition to Indians, Sal also idealizes African Americans and their way of life. When he is in New Orleans, Sal sees African Americans working on the ferries. "Negroes were working in the hot afternoon, stoking the ferry furnaces that burned red and made our tires smell. Dean dug them, hopping up and down in the heat" (Kerouac, 2000, pp. 127). He paints a vibrant picture of community when describing African-Americans, and ignores all else. Instead of seeing men putting in hours of gruelling labour, he sees beautiful images of "furnaces burning red," indicating a realness about their work. Critic Carole Vopat writes of Sal and his fellow travellers, "...they idolize Negroes as romantic and carefree children, seeing them in the ghetto not the reality of poverty and oppression, but freedom from responsibility and hence, joy" (Vopat, 2000, pp.196). Vopat illustrates the manner in which Sal and his friends see the African-Americans' ambient spatial experience as a happy, untroubled one. In doing so, they fail to see the difficulty of incorporating in their spatial environment poverty, destruction and despair that wracks AfricanAmerican neighbourhoods. Despite the adversities African Americans face, Sal says, "I walked with every muscle aching, wishing I were a Negro" (Kerouac, 2000, pp. 163-64). Sal longs to partake in African American culture and deems the lifestyle superior to his own, thereby reducing his beliefs and traditions to a state of worthlessness, which results in him not being able to 'assimilate' and 'accommodate' in his own spatial existence.

In Sal's inner space, the jazz musician in his element has surpassed the point of authenticity that Sal seeks for himself. In reference to a jazz musician named Slim, critic Rachel Ligairi writes,

"They seem to embody of the principle of originality that Sal and Dean envy. Yet, the jazz musician is not of the same world as Kerouac's characters-Slim is neither anxious to get to New York nor game for the wife-swapping Beat lifestyle" (Ligairi, 2009, pp.147).

Sal and Dean think they want to be exactly like Slim, but in reality, their lives and principles are completely different, eventually leading Sal down a path of disenchantment. He loves the company and entertainment of the musicians, but when the night is over he feels "...as miserable- 
looking as anybody could be..." (Kerouac, 2000, pp. 244). Tired and discontent with himself, Sal cannot live in the manner of a jazz musician. Sal does not fully understand the implications of regarding these musicians as higher beings and continues to idealize them as he does with the others he meets during his temporal journey.

Sal idealizes not only musicians, but also the inhabitants of Los Angeles. To Sal, L.A. is a mass of enchantment and excitement. Sal observes that "the most beautiful little gone gals in the world cut by in slacks; they came to be starlets, they ended up in drive-ins" (Kerouac, 20oo, pp. 78). It astonishes Sal to think that so many "beautiful" girls are rejected by Hollywood, contributing to his fascination with the city. He does not even regard L.A. as being tangible. "[...] Sal sees the city in terms of a mirage-a shimmering but insubstantial vision" (Ligairi, 2009, pp. 149). His idealizations of the city lead him to future discontent with himself when he realizes how his own life pales in comparison to those in L.A. On his way home for the first time, Sal finds himself in a rather degrading position with the fabulous city all around him.

"All around me were the noises of this crazy gold-coast city. And this was my Hollywood career-this was my last night in Hollywood, and I was spreading mustard on my lap in back of a parking-lot john" (Kerouac, 2000, pp. 93).

Instead of living a glamorous lifestyle, Sal has ended up alone, making himself sandwiches in preparation to hitchhike across the country. Feeling empty and defeated, he continues back to New York because the places he idealizes do not necessarily express and reflect the inward space of the subject. Consequently, the ambient space he wants to create never attains the quality of existential space.

Out of those he idealizes Sal is most captivated by Dean, his guide and inspiration for going on the road. In fact, Sal tells the reader directly, "With the coming of Dean began the part of my life you could call my life on the road" (Kerouac, 2000, pp. 1). For Sal, Dean is the symbolic representation of his journey and his quest. In fact, Dean generally dictates Sal's life on the road, coaxing Sal to adventure around the country with him. Throughout the journey depicted in the novel, Dean's personal space represents for Sal the existential space of his quest. As Sal has this vibrant personality beside him all the way on the road, he sees his own life as lackluster and boring. Next to Dean and his wild friends, Sal believes “...I was a lout compared, I couldn't keep up with them” (Kerouac, 2000, pp. 7). His inward space feels overwhelmed by Dean's huge personality, yet craves Dean's energy. Sal describes Dean as a "long-lost brother" (Kerouac, 2000, pp. 7). Dean is his counterpart, an embodiment of the energy and authenticity he wishes to have. Sal goes out of his way to call Dean divine. Observing Dean towards the end of the novel, Sal recognizes that "He was finally an Angel, as I always knew he would become; but like any Angel he still had rages and furies..." (Kerouac, 2000, pp. 263). Critic Carl Malmgren explains Sal's feelings: "Dean epitomizes life on the road for Sal, as numerous passages make clear, and his narrative about road life necessarily evolves into the story of his relation with Dean" (Malmgren, 1990). Malmgren reveals that Dean displays not the usual qualities Sal searches for in people and places he idealizes, but a standard to look up to while travelling on the road. Out of all those that he idealizes, Sal's view of Dean defines his aspirations and disappointments on the road.

Sal's idealizations cause him to disconnect from reality, becoming blissfully unaware of the awful spatial-temporal circumstances surrounding some of the people he idolizes. Sal claims, "Every day I earned approximately a dollar and a half" (Kerouac, 2000, pp. 88). Even for the 1940s, the time period of On the Road, a dollar and a half is certainly not enough to support a family on. However, he complains of the back-breaking work and focuses on his own feelings, rather than understanding that he has led himself, Terry and Terry's seven-year-old son into a life-threatening 
cycle of poverty. "What Sal enthuses over as 'a California home' Kerouac reveals as a place of poverty, frustration, anger and despair, but Sal's raptures cushion him from recognizing the grimness of the existence to which he is carelessly consigning his mistress and her small son, a child he had called 'my boy' and played at fathering" (Vopat, 200o, pp. 196). Critic Carole Vopat encapsulates the manner in which Sal's idealizations lead to a total misperception of reality. Sal's separation from reality causes him to make wrong decisions without taking responsibility for them, only further skewing his perspective on reality and his own existential space.

After years spent wandering the country and idealizing the people he meets, Sal achieves somewhat of an internal stability by realizing his perspective is not clear. Critic Tim Hunt writes that by the time of Sal's last trip,

"Sal is free of the illusion that the trip will resolve anything...Sal is able and willing to see clearly what he encounters. Things are no longer the greatest or most fantastic" (Hunt. 2004, pp. 61).

Hunt indicates that Sal has abandoned his manner of overemphasizing everything. Finally, Sal realizes that the "authentic" he has been looking for in different spatial contexts is simply a life which he accepts, an ambient space which can be constructed through his hodological space. Sal's transition to acceptance is gradual; he does not experience any epiphany. On his last few ventures on the road he begins to change his mind set. An indication of Sal's first changes is his encounter with Henry Glass, an ex-convict who tries to initiate conversation with him on a bus to Denver.

"Here was a young kid like Dean had been; his blood boiled too much for him to bear; his nose opened up; but no native strange saintliness to save him from the iron fate" (Kerouac, 2000, pp. 234).

Glass has the same passion and excitement as Dean, his "blood boiling." Sal indicates Glass's lack of "saintliness", the divine quality that Dean possesses and does not immediately idolize Glass's zest for life. In fact, he looks upon Glass with pity. Critic Tim Hunt states that "Sal in no way romanticizes Glass even though superficially he is of a type with Dean" (Hunt, 2004, pp. 62). Sal even compares him with Dean, but at this point in Sal's journey, he is no longer apt to picture Henry Glass as a perfect example of liveliness and authenticity. Sal's abandonment of exaggerated feelings leads to him learning to live for reality and not for his old warped perceptions of a 'promised land'.

When Sal returns to New York from Mexico, he meets a girl and resolutely decides to be with her for who she is, beginning an unwavering life unlike the mayhem and chaos he has experienced on the road. Sal claims that

"...I went up and there she was, the girl with the pure and innocent dear eyes that I had always searched for and for so long. We agreed to love each other madly" (Kerouac, 2000, pp. 277-278).

Finally Sal has found someone that he loves for who she is and not the exotic culture she represents, as he did with Terry earlier in the novel. Sal describes his new love as having "pure and innocent eyes" signifying that his love for her comes from true passion, not a desire for someone new and interesting. Finding a stable relationship signifies that Sal is ready to settle down in a patterned life without yearning for more. He has exhausted his need to search for the authentic, coming to an acceptance with himself that enables him to modify his own spatial behaviour in accordance with his spatial environment, and thereby maintains the Schemata. 
Another integral part of self-acceptance for Sal is his parting with Dean. As difficult as the task is for him, Sal frees himself from being influenced by Dean's own inward space, ending his relationship with the tumultuous road that gives him no direction; rather it throws him out of his own 'centre'. He looks with sadness upon Dean's departure from his life, but at the same time he is able to transit into a more authentic existential plain in comparison to his childlike wandering through the unending path. He accepts that "Old Dean's gone" (Kerouac, 2000, pp. 307) and knows that he can carry on without him. Sal has retained some of the qualities of the road but has abandoned his worst tendency, idealizing the road as his own existential space. Putting an end to this fruitless quest has allowed Sal to gain a clearer perspective of the world and in turn live a more fulfilled life.

\section{Conclusion}

Sal begins his journey across America searching for an authentic lifestyle. He only finds what he is seeking when he idealizes the people he meets along the way, inadvertently causing himself disappointment with his own life. When Sal finally starts to free himself of this lopsided perception of others, he begins to accept himself. In a way, his quest is resolved. "For him, this relativity confirms the desires he has had all along: that American norms are not at the center of humanity. It seems to justify his past differences with his nation's set of proprieties and responsibilities and permits him to explore them in the future" (Larson, 2009, pp. 47). Critic Lars Larson confirms that Sal has reached a stable point in his life, signifying to the reader that correcting a skewed viewpoint is possible. Sal Paradise teaches readers a valuable lesson: perceptions of others can easily determine one's satisfaction with life. Dropping a skewed perspective is the first step to contentment with life.

\section{Acknowledgement:}

We are thankful to Prof. Rajni Singh, Associate Professor, Indian Institute of Technology (ISM, Dhanbad), for her valuable guidance in writing down the paper.

\section{References:}

Banerjee, S., Singh, R., \& Basu, A. (2016). The Transcendental Self: Demystifying Pāñcālĩ in Chitra Banerjee Divakaruni's The Palace of Illusions. Archiv Orientalni, volume 84, (pp. 276-278). Czech Republic.

Benedikt, M. (1991). Cyberspace: Some Proposals. In M. Benedikt (Eds.), Cyberspace, First Steps (p.125). London: MIT Press.

Buber, I and Thou, 1937.

Charitos, D. (1996). Definining Existential Space in Virtual Environments. Proc. Virtual Reality World 96. Stuttgart: IDG Publications.

Feied, Frederick. (1964). No Pie in the Sky. New York: Citadel P.

Heidegger, M. (1971). Building, Dwelling, Thinking. In Poetry, Language, Thought. New York: Harper \& Row.

Holladay, Hilary. (2009). Parallel Destinies in The Bell Jar and On the Road. In H. Holladay \& R. Holton (Eds.), What's Your Road, Man? (pp.99-117). Carbondale: Southern Illinois University Press. 
Hunt, Tim. (1981). An American Education. Kerouac's Crooked Road: Development of a Fiction. North Haven: Archon Books. Rpt. In H. Bloom (Eds.), Jack Kerouac's On the Road (pp. 27-75). Philadelphia: Chelsea House Publishers, 2004.

Kerouac, Jack.(200o). On the Road. London: Penguine Books.

Krupat, Arnold. (1979). Dean Moriarty as Saintly Hero. In S. Donaldson (Eds.), On the Road. Text and Criticism (pp.397-410). New York: Viking.

Larson, Lars. (2009). Free Ways and Straight Roads: the Interstates of Sal Paradise and 1950s America. In H. Holladay \& R. Holton (Eds.), What's Your Road, Man? (pp.35-59). Carbondale: Southern Illinois University Press.

Lewin, K. (1938, reprinted in 1968 by Johnson Reprint Corporation). The Conceptual Representation and the Measurement of Psychological Forces. Durham, USA: Duke University Press.

Ligairi, Rachel. (2009). When Mexico Looks Like Mexico: the Hyperrealization of Race and the Pursuit of the Authentic. In H. Holladay \& R. Holton (Eds.), What's Your Road, Man? (pp. 139-154). Carbondale: Southern Illinois University Press.

Malmgren, Carl D. (1990). On the Road Reconsidered: Kerouac and the Modernist Tradition. In R. Matuz (Eds.), Contemporary Literary Criticism. Vol. 61. (pp.289-292). Detroit: Gale Research Inc.

Merleau-Ponty, M. (1962). The Phenomenology of Perception. London: Routledge.

Mitropoulos, E.G. (1975). Space Networks: Toward Hodological Space Design for Urban Man. Ekistics 232. March 75 .

Phillips, Lisa and Berger, Maurice. Beat Culture and the New America. Whitney Museum of American Art in association with Flammarion, Manhattan, 1995.

Relph, E. (1976). Place and Placelessness. London: Pion.

Schulz, Norberg. (1971). C. Existence. Space and Architecture. New York: Praeger Ltd.

Sarin, Indu. (1996). Kierkegaard: A Turning Point. Delhi: Renaissance.

Tytell, John. (1979). The Broken Circuit. In S. Donaldson (Eds.), On the Road: Text and Criticism (pp. 313341). New York: Viking.

Vopat, Carole G. (1979). A Re-Evaluation of On the Road. In S. Donaldson (Eds.) On the Road. Text and Criticism (pp.431-450). New York: Viking.

Vopat, Carole G. (200o). Jack Kerouac's On the Road: A Re-evaluation. In M.R. Napierkowski \& D. Stanley, et. al. (Eds.), Novels for Students. Vol. 8. (pp. 195-201). Detroit: Gale.

Webb, Howard C. (1964). The Singular Worlds of Jack Kerouac. In J.J. Waldmeir (Eds.), Contemporary American Novelists(pp. 120-133). Carbondale: Southern Illinois UP.

Widmer, Kingsley. (1965). The Literary Rebel. Carbondale: Southern Illinois UP. 